\title{
Foraging ecology of short-tailed shearwaters near the Pribilof Islands, Bering Sea
}

\author{
George L. Hunt, $\mathrm{Jr}^{1, *}$, Kenneth O. Coyle ${ }^{2}$, Susan Hoffman ${ }^{1, * *}$, Mary Beth Decker ${ }^{1}$, \\ Elizabeth N. Flint ${ }^{1, * * *}$
}

'Department of Ecology and Evolutionary Biology, University of California, Irvine, California 92697, USA

${ }^{2}$ Institute of Marine Sciences, University of Alaska, Fairbanks, Alaska 99775-1080, USA

\begin{abstract}
We studied short-tailed shearwaters Puffinus tenuirostris foraging near the Pribilof Islands, Alaska, USA, during the summers of 1987, 1988, and 1989. Their foods were almost exclusively the euphausiid Thysanoessa raschii, which they obtained both from near-surface swarms and from epibenthic layers. Near-surface mating swarms of euphausiids occurred in areas of elevated phytoplankton standing stocks near inshore tidal fronts. Many of these euphausiids had attached spermatophores. Shearwaters also obtained euphausiids over shallow reefs and inshore of the fronts where euphausiids were trapped in water shallower than $40 \mathrm{~m}$ by irregulanties in bottom topography' ("bathymetric traps'). We hypothesize that the largely inshore distribution of shearwaters in the southeastern Bering Sea described by previous workers is the result of attraction of shearwaters to frontal areas where euphausiids may forage on phytoplankton stocks throughout the summer. These areas, when shallower than $40 \mathrm{~m}$, would also permit shearwaters 10 access epibenthic aggregations of euphausiids during daylight, when euphausiids not engaged in matung swarms usually migrate to depth.
\end{abstract}

KEY WORDS: Short-tailed shearwater - Puffinus tenuirostris · Euphausiids. Thysanoessa raschii Seabird foraging · Fronts - Bering Sea

\section{INTRODUCTION}

Short-tailed shearwaters Puffinus tenuirostris migrate annually from their breeding colonies in southeastern Australia to spend the austral winter in the North Pacific (Shuntov 1964, Tanaka \& Kajihara 1979, Guzman 1981, Gould et al. 1982). Millions of these birds forage in the Bering Sea between April and October (Schneider \& Shuntov 1993), where they eat predominantly euphausiids, in particular, Thysanoessa raschii and $T$ inermis (Ogi 1973, Ogi et al. 1980. Hunt et al. 1981a, Schneider et al. 1986. Troy \& Johnson 1989, Troy \& Bradstreet 1991). In the Bristol Bay region of the southeastern Bering Sea, Ogi et al. (1980) esti-

-E-mail: glhunt@uci.edu

Present addresses:

"Department of Biology, California State University, Long Beach, California 90840, USA

-.Hawaiian Islands National Wildlife Refuge, US Fish and Wildlife Service, PO Box 50167, Honolulu, Hawail 96850. USA mated that shearwaters consume at least $30000 \mathrm{t}$ of euphausiids annually, a consumption roughly equivalent to the consumption of euphausiids by sockeye salmon Oncorhynchus nerka during the month that they reside in Bristol Bay before ascending rivers to spawn (Nishiyama 1974). To forage efficiently, shearwaters would profit from mechanisms that permit euphausiids to be predictably harvested. Discovery and understanding of these mechanisms are important because, as shearwaters are the greatest component of avian biomass in the eastern Bering Sea, their foraging distribution and high prey consumption impact the ecosystem (Schneider et al. 1986). Their prey consumption will have its greatest impact if it is highly concentrated in space or time and conflicts with the needs of other high trophic level organisms

Key to understanding the foraging ecology of shorttailed shearwaters in the southeastern Bering Sea is identification of the circumstances in which they are able to capture euphausiids. Short-tailed shearwaters forage by pursuit diving from the surface, plunging 
from above the surface, seizing prey at the surface, and hydroplaning, a foot-propelled movement at the surface in which the head and back may be beneath the surface while the wings are held out of the water (Ogi et al. 1980. Morgan 1982). In the eastern Bering Sea, short-tailed shearwaters frequently forage in flocks of tens of thousands or more, with major concentrations of these flocks occurring in an arc from the eastern passes of the Aleutian Islands along the coast into Bristol Bay and then northwestward over the nearshore waters to Nunivak Island (Guzman 1981, Hunt et al. 1981c, Gould et al. 1982. Troy \& Johnson 1989). Schneider \& Shuntov (1993) reviewed data showing that these large shearwater aggregations are associated with the $50 \mathrm{~m}$ isobath, near the inner front (Schumacher et al. 1979, Kinder \& Schumacher 1981), throughout the eastern and western Bering Sea, as well as in the shallow passes of the Aleutian and Commander Islands.

A tidal front, similar to the inner front of the southeastern Bering Sea (Schumacher et al. 1979, Kinder \& Schumacher 1981), occurs in the vicinity of the $50 \mathrm{~m}$ isobath around St. Paul and St. George Islands in the Pribilof Islands of Alaska, USA (Kinder et al. 1983). At St. Paul Island, this front separates well-mixed inshore waters from strongly stratified middle domain water; at St. George Island, the front demarks the transition between a well-mixed nearshore regime and the waters of the outer domain (Coyle \& Cooney 1993).

Vertical mixing at fronts is likely to support local phytoplankton blooms over a longer period than would stratified waters of the shelf, which become nutrient depleted after the spring bloom (Sambrotto et al. 1986, Whitledge et al. 1986; see also Pingree et al. 1975, Simpson et al. 1979, and Le Fèvre 1986 for a review). For example, in August 1987, high phytoplankton biomass was present above the thermocline just seaward of the fronts surrounding the Pribilof Islands, as were large concentrations of euphausiids (Thysanoessa raschii near St. Paul Island and $T$ inermis on the south side of St. George Island; Coyle \& Cooney 1993). Elsewhere, frontal regions with enhanced phytoplankton production also support elevated and prolonged production of zooplankton (Kiørboe et al. 1988, Kiørboe 1993, Nielsen et al. 1993), and planktivorous predators such as fish larvae (e.g. Kiørboe et al. 1988) and seabirds (see Hunt \& Schneider 1987 and Hunt 1991 for reviews) frequently aggregate in frontal regions to forage.

In this paper we investigate the roles of tidal fronts and irregularities in the bottom that can block the downward migration of euphausiids along a sloping bottom as features of the marine environment important for successful foraging by shearwaters in the Bering Sea. In the 1970s, few short-tailed shearwaters were seen near the Pribilof Islands, and no feeding flocks were seen (Hunt et al. 1981b) In contrast, during surveys around the islands in 1987 and 1988 (Coyle \& Cooney 1993, Hunt unpubl.), we saw high numbers of short-tailed shearwaters, including flocks of feeding birds. In 1989, we investigated the foraging ecology of these shearwaters by analyzing the distribution and behaviors of shearwaters in relation to prey biomass and bottom topography in the vicinity of St. Paul Island.

\section{METHODS}

The distribution and abundance of short-tailed shearwaters, acoustically determined biomass and phytoplankton were assessed in the vicinity of St. Paul and St. George Islands in 1987, between 28 July and 16 August, and in 1988, between 28 July and 20 August. Surveys extended approximately 40 nautical miles (n miles) (74 km), weather permitting, from these islands (Figs. 1 \& 2; see also Coyle \& Cooney 1993). In 1989, between 6 and 14 August, we focused our surveys in the region north of St. Paul where we encountered large numbers of foraging shearwaters in the vicinity of a frontal system (Coyle \& Cooney 1993), and to the east of St. Paul where large flocks of foraging shearwaters were also encountered.

Counts of shearwaters and other seabirds were made from the bridge of the RV 'Alpha Helix' (eye height $7.7 \mathrm{~m}$ above the sea surface) while the ship was underway. Vessel speeds varied from about $15 \mathrm{~km} \mathrm{~h}^{-1}$ when we were conducting echosounder surveys to about $19 \mathrm{~km} \mathrm{~h}^{-1}$ when we were not deploying the transducer. Birds were counted continuously in a $300 \mathrm{~m}$ arc from directly ahead of the vessel to $90^{\circ}$ off the side with the best visibility (least glare). The continuous count of flying birds (as opposed to a snap-shot method, see Tasker et al. 1984) overestimates the density of flying birds on the transect line (van Franeker 1994), but provides an estimate of avian movements in an area (Hunt et al. 1994). Data on flying birds are depicted as birds counted per $9.3 \mathrm{~km}$ of survey, the distance between oceanographic stations which required $0.625 \mathrm{~h}$ to cover at $15 \mathrm{~km} \mathrm{~h}^{-1}$; counts of birds on the water or feeding are presented as numbers $\mathrm{km}^{-2}$ Areas surveyed were determined by multiplying the distance traveled, as determined by satellite navigation, by the width of the transect surveyed.

Shearwater behaviors were recorded as flying (with flight direction), sitting on the water, and feeding. We defined feeding birds as those which were hydroplaning, plunge diving at shallow angles into the water, or making pursuit dives from the surface. For the purpose of this analysis, we assumed that birds sitting on the 

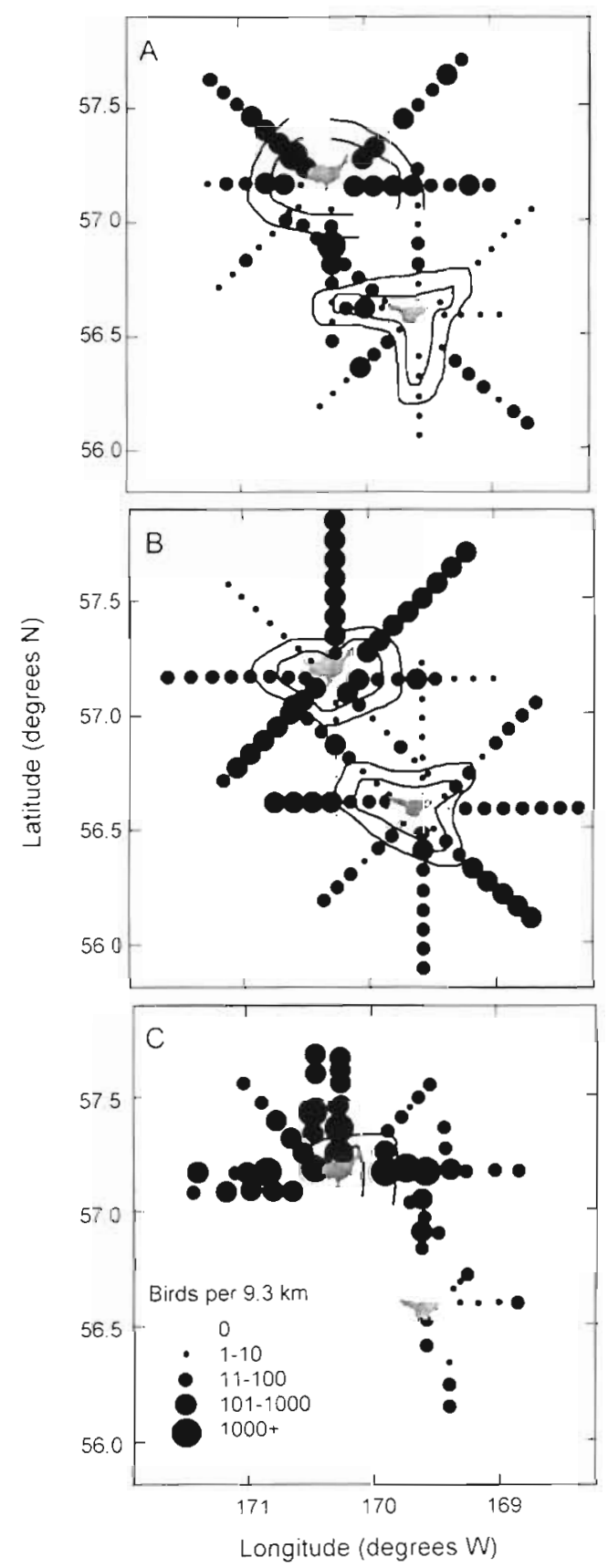

Fig. 1 Distribution and rate of encounter with short-tailed shearwaters in tlight (birds $9.3 \mathrm{~km}^{-1}$ of survey track): (A) 28 July to 16 August 1987 ; (B) 28 July to 20 August 1988 ; and (C) 6 to 14 August 1989. Upper island is St. Paul, lower island is St. George (Alaska, USA); solid lines indicate approximate locations of the tidal fronts around each island, as determined by CTD casts

water had previously fed in the vicinity of where they were resting We determined the shearwaters' prey by shooting 3 to 5 birds per flock from flocks of birds that were foraging. We limited our collections to foraging birds so that we could be certain that the birds had ob-

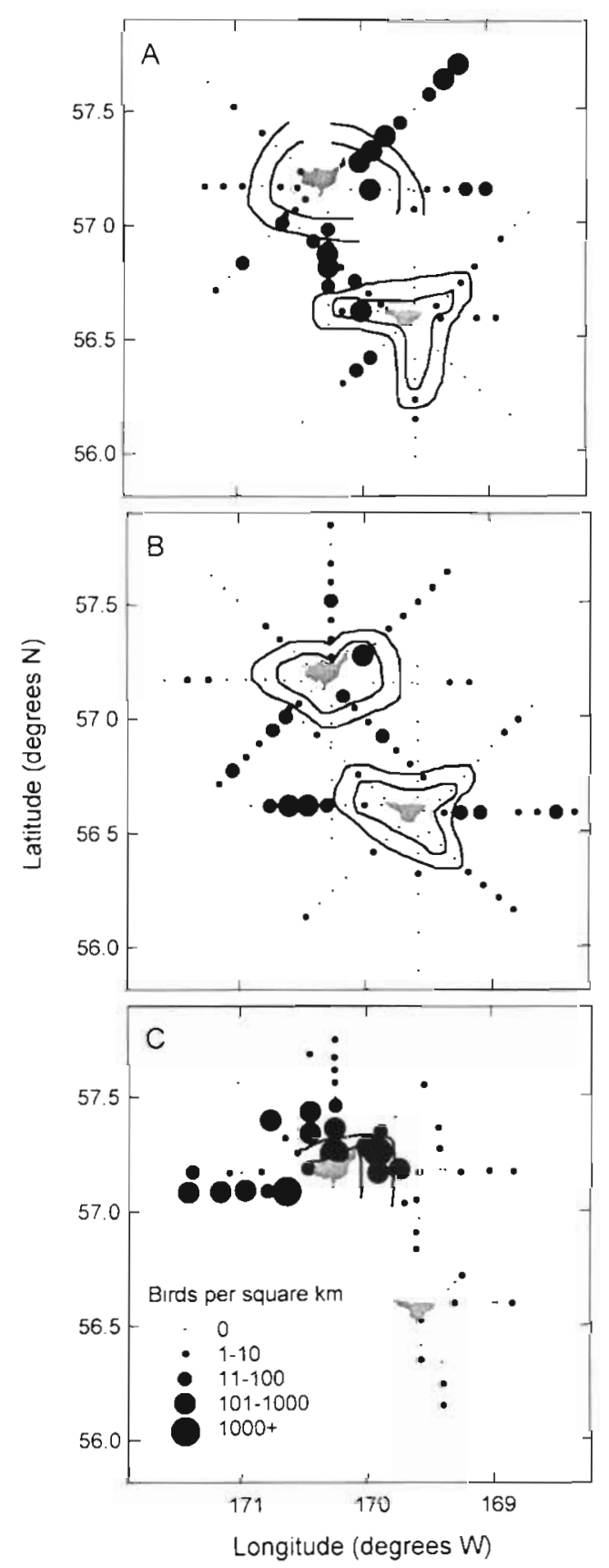

Fig. 2. Distribution and density (birds $\mathrm{km}^{-2}$ ) of short-tailed shearwaters that were either feeding or resting on the water: (A) 28 July to 16 August 1987; (B) 28 July to 20 August 1988 ; and (C) 6 to 14 August 1989. Upper island is St. Paul, lower island is St. George; solid lines indicate the approximate locatıons of the tidal fronts around each island, as determuned by CTD casts

tained their prey near where we collected them. We restricted our collections to 5 birds per flock because initial inspection showed that all birds collected had taken similar prey and thus larger samples would not have significantly increased our knowledge of prey use. 
Table 2. Distribution of short-taled shearwater numbers with respect to an oceanographic frontal system north of St. Paul Island in 1989. Proportion of effort or counts in parentheses

\begin{tabular}{|c|c|c|c|c|c|c|}
\hline & \multicolumn{5}{|c|}{ Location } & \multirow{2}{*}{ Total } \\
\hline & Inshore & $\begin{array}{l}2 \text { n miles } \\
\text { inshore } \\
\text { of front }\end{array}$ & $\begin{array}{c}4 \text { n miles } \\
\text { frontal } \\
\text { zone }\end{array}$ & $\begin{array}{c}2 \mathrm{n} \text { miles } \\
\text { offshore } \\
\text { of front }\end{array}$ & Offshore & \\
\hline $\begin{array}{l}\text { Minutes of survey } \\
\text { effort }\end{array}$ & $\begin{array}{c}52 \\
(0.095)\end{array}$ & $\begin{array}{c}72 \\
(0.132)\end{array}$ & $\begin{array}{r}152 \\
(0.279)\end{array}$ & $\begin{array}{c}72 \\
(0.132)\end{array}$ & $\begin{array}{c}196 \\
(0.360)\end{array}$ & $\begin{array}{r}544 \\
(0.998)\end{array}$ \\
\hline $\begin{array}{l}\text { Shearwaters } \\
\text { observed flying }\end{array}$ & $\begin{array}{c}413 \\
(0.059)\end{array}$ & $\begin{array}{c}1989 \\
(0.283)\end{array}$ & $\begin{array}{r}2661 \\
(0.380)\end{array}$ & $\begin{array}{c}564 \\
(0.080)\end{array}$ & $\begin{array}{c}1388 \\
(0.198)\end{array}$ & $\begin{array}{r}7015 \\
(1.000)\end{array}$ \\
\hline $\begin{array}{l}\text { Shearwaters } \\
\text { observed on water } \\
\text { or feeding }\end{array}$ & $\begin{array}{c}424 \\
(0.011)\end{array}$ & $\begin{array}{l}7236 \\
(0.187)\end{array}$ & $\begin{array}{l}30431 \\
(0.785)\end{array}$ & $\begin{array}{c}535 \\
(0.014)\end{array}$ & $\begin{array}{c}131 \\
(0.003)\end{array}$ & $\begin{array}{l}38757 \\
(1.000)\end{array}$ \\
\hline
\end{tabular}

Table 3. Comparison of expected and observed distributions (proportions) of short-tailed shearwaters, by behavior, with respect to an oceanographic front north of St. Paul Island in 1989. Expected proportion based on time spent surveynng zone. Confidence intervals on the proportion of shearwaters observed were constructed for a per family Type I error rate of $\alpha=0.05$ (Family $=$ flying, feeding or on water); $\mathrm{p}_{1}=$ true proportıon of birds in that behavior category in a partıcular zone

\begin{tabular}{|c|c|c|c|c|c|}
\hline & Inshore & $\begin{array}{l}2 \mathrm{n} \text { miles } \\
\text { inshore } \\
\text { of front }\end{array}$ & $\begin{array}{l}4 \mathrm{n} \text { miles } \\
\text { in frontal } \\
\text { region }\end{array}$ & $\begin{array}{l}2 \text { n miles } \\
\text { offshore } \\
\text { of tront }\end{array}$ & Offshore \\
\hline $\begin{array}{l}\text { Expected proportion } \\
\text { of birds }\end{array}$ & 0.095 & 0.132 & 0.279 & 0.132 & 0.360 \\
\hline $\begin{array}{l}\text { Confidence interval } \\
\text { around true proportion } \\
\text { of flying birds }\end{array}$ & $0.052 \leq p_{1} \leq 0.066$ & $0.270 \leq p_{1} \leq 0.297$ & $0.364 \leq p_{1} \leq 0.394$ & $0.077 \leq \mathrm{p}_{1} \leq 0.081$ & $0.183 \leq p_{1} \leq 0.213$ \\
\hline $\begin{array}{l}\text { Confidence interval } \\
\text { around true proportion } \\
\text { of birds on water or feed }\end{array}$ & $0.009 \leq p_{i} \leq 0.0123$ & $0.182 \leq p_{1} \leq 0.192$ & $0.780 \leq p_{1} \leq 0.791$ & $0.0123 \leq p_{1} \leq 0.0153$ & $0.003 \leq p_{1} \leq 0.004$ \\
\hline
\end{tabular}

shelf-dwelling Thysanoessa raschii are vertical migrators, descending to depth during the day (Ponomareva 1963). During the summer months, members of the genus Thysanoessa may form daytime near-surface and surface swarms for mating (Smith \& Adams 1988 , Hanamura et al. 1989). Breeding by $T$ raschii appears to occur in the presence of elevated phytoplankton densities (Paul et al. 1990) It is of interest to examine the predictability of where shearwaters are likely to encounter euphausiids vulnerable to predation. We suggest that 3 mechanisms may support the vast majority of short-tailed shearwater foraging in the southeastern Bering Sea. foraging at euphausijd mating swarms in frontal regions, foraging at depth on euphausiids trapped on the bottom inshore of tidal fronts, and foraging where tidal currents force euphausiids to remain in shallow water, such as may occur in the Aleutian passes.

Fluorescence measurements in the vicinity of the tidal fronts surrounding the Pribilof Islands indicate the presence of elevated levels of phytoplankton (Schneider et al. 1990. Coyle \& Cooney 1993) relative to the stratified waters of the southeastern Bering Sea, where, beginning in June, nutrient limitation leads to low phytoplankton production and standing stocks (Sambrotto et al. 1986, Whitledge et al. 1986). In summer, tidal fronts, such as the front on the north side of St. Paul Island or the inner front of the southeastern Bering Sea, may have elevated levels of phytoplankton in comparison to stratified offshore waters as a result of enhanced vertical flux of nutrients and in situ production (Pingree et al. 1975. Simpson et al. 1979, see Le Fèvre 1986, Kiørboe 1993 for reviews). In other frontal systems, enhanced zooplankton production has been associated with enhanced phytoplankton production in the frontal region (Richardson 1985, Kiorboe et al. 1988, Kiorboe 1993).

Summertime near-surface foraging of shearwaters may be associated with euphausid mating swarms. Spermatophores occurred on many of the euphausiids found in the stomachs of the shearwaters, some of which were foraging at or just beneath the water's surface. In these cases, we conclude that the shearwaters were obtaining euphausiids that were or had recently 

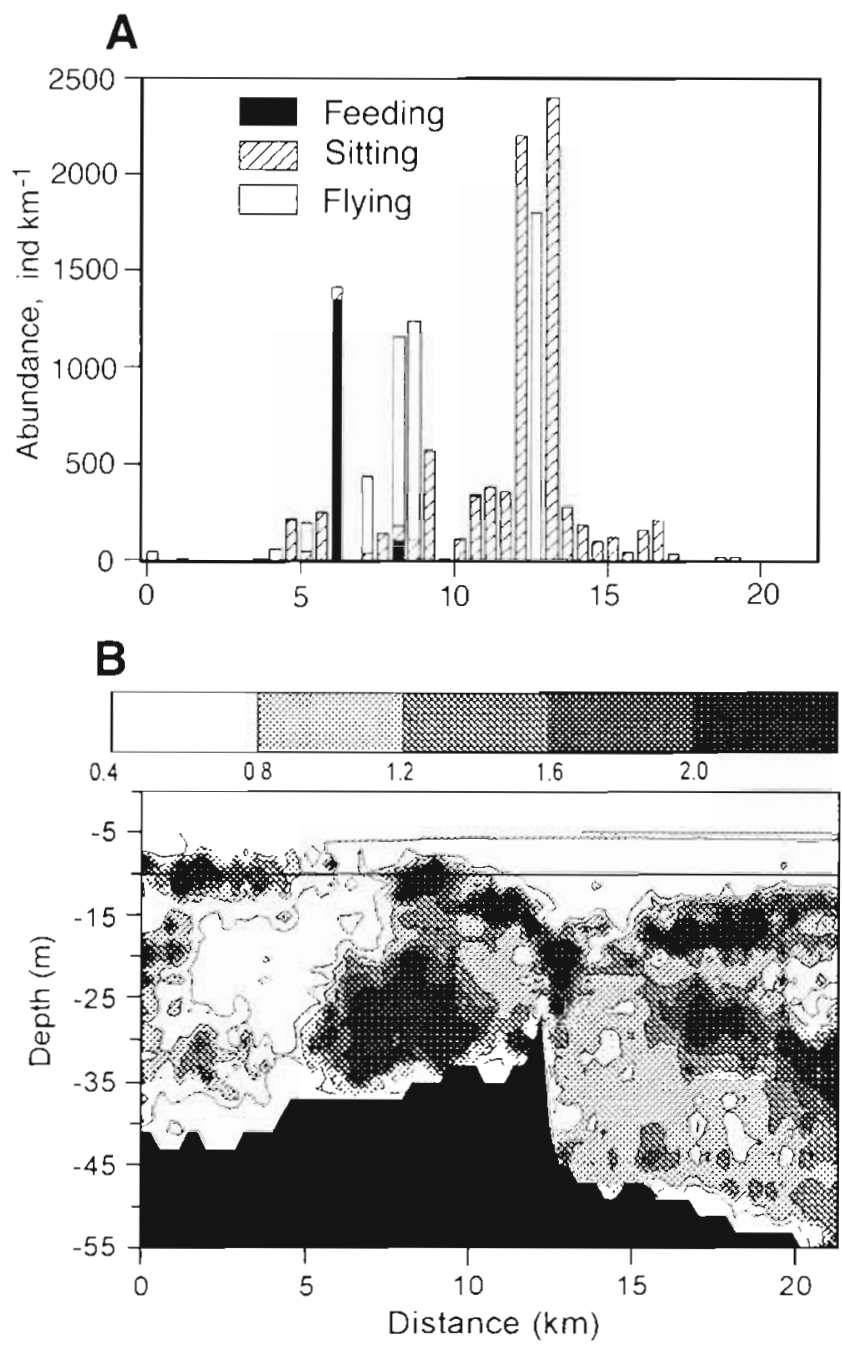

Fig. 5. Observations east of St. Paul Island, 14 August 1989. (A) distribution of short-tailed shearwaters in birds $\mathrm{km}^{-1}$ between 1252 and $1412 \mathrm{~h} \mathrm{ADT}$; and (B) acoustically estimated biomass in $\mathrm{g} \mathrm{m}^{-3}$ over a shallow underwater reef

been in mating swarms. We hypothesize that these mating swarms would be most frequently encountered near fronts. We hypothesize further that patches of near-surface phytoplankton associated with the tidal fronts in the southeastern Bering Sea provide the food necessary to sustain mating swarms of euphausiids long after near-surface phytoplankton concentrations away from the front have decreased. These concentrations of surface swarms of euphausiids could result in the aggregation of foraging shearwaters in the vicinity of fronts. The predominately coastal distribution of short-tailed shearwater flocks in Bristol Bay and the southeastern Bering Sea (Guzman 1981, Hunt et al. 1981c, Gould et al. 1982, Troy \& Johnson 1989) fits with this prediction, although we lack the data necessary to demonstrate the validity of the proposed mechanism for determining this distribution.

Shearwater foraging at the Pribilof frontal systems is of particular interest because it is the first documented case of marine birds foraging at a front when the proposed mechanism for enhanced prey availability was the result of prey attraction to elevated phytoplankton concentrations at the front. In other cases of birds foraging at fronts, either the mechanism was not identified, or the zooplankton had been aggregated by physical forcing associated with frontal processes (Hunt 1991, Franks 1992).

We also found short-tailed shearwaters foraging over epibenthic patches of acoustically located biomass which net tows revealed to contain euphausiids (Coyle \& Cooney 1993). These patches were at depths of between 30 and $45 \mathrm{~m}$. Epibenthic patches of euphausiids at depths greater than $40 \mathrm{~m}$ were rarely attended by foraging or sitting shearwaters. We observed what we interpreted as the bubble tracks of diving shearwaters down to depths of about $30 \mathrm{~m}$, considerably deeper than the $20 \mathrm{~m}$ maximum dive depth estimated by Morgan (1982) for short-tailed shearwaters in the Southern Hemisphere. Thus, we would expect that short-tailed shearwaters could capture euphausiids between the surface and 30 or $40 \mathrm{~m}$ depth.

We hypothesize that depressions in the tops of reefs and ridges across the slope of the escarpment surrounding the islands may trap euphausiids as they

Table 4. Presence of aggregations of short-talled shearwaters in relation to prey depth or depth of bottom, and whether prey was detected under the flock, north and east of St. Paul lsland in 1989

\begin{tabular}{|c|c|c|c|c|}
\hline & \multicolumn{4}{|c|}{ Depth of top of prey concentration or of the seafloor, when no prey detected (m) } \\
\hline & $20-29$ & $30-39$ & $40-49$ & $50-59$ \\
\hline Feeding shearwaters & $\begin{array}{c}1 \text { flock, no prey } \\
2 \text { flocks with prey }\end{array}$ & $\begin{array}{c}1 \text { flock, no prey } \\
3 \text { flocks with prey }\end{array}$ & No flocks & No flocks \\
\hline Resting shearwaters & 1 flock with prey & $\begin{array}{l}3 \text { flocks, no prey } \\
3 \text { flocks with prey }\end{array}$ & 1 flock with prey & 1 flock, no prey \\
\hline $\begin{array}{l}\text { Prey concentration } \\
\text { detected, no shearwater } \\
\text { concentration present }\end{array}$ & $\begin{array}{l}\text { No prey concentrations } \\
\text { r without } \\
\text { shearwaters }\end{array}$ & $\begin{array}{c}\text { No prey concentrations } \\
\text { without } \\
\text { shearwaters }\end{array}$ & $\begin{array}{c}4 \text { prey concentrations } \\
\text { without } \\
\text { shearwaters }\end{array}$ & $\begin{array}{c}4 \text { prey concentrations } \\
\text { without } \\
\text { shearwaters }\end{array}$ \\
\hline
\end{tabular}


attempt to migrate downward in the morning. These depressions or 'bathymetric traps' can prevent downward-migrating euphausiids from descending farther because to do so, the euphausiids would have to reverse their downward migration and move toward the surface to clear the edge of the depression or the ridge. Where euphausiids are trapped against the bottom at depths of $40 \mathrm{~m}$ or less, they are vulnerable to predation by shearwaters. Euphausiids are unlikely to be trapped by bottoms with extremely steep slopes, such as those on the south side of St. George Island, because they will be able to move deeper while 'in contact' with the bottom. Where the bottom is flat, as it is on the reefs east of St. Paul Island, or slopes gently with ridges and gullies normal to the slope, as it does on the north side of St. Paul Island, there is a greater likelihood of the euphausiids being trapped at a shallow depth.

In the present study, concentrations of foraging or sit ting short-tailed shearwaters north of St. Paul Island were at or within $2 \mathrm{n}$ miles inshore of the tidal front. Because most bathymetrically trapped euphausiids attended by short-tailed shearwaters will be at depths of less than $40 \mathrm{~m}$, these aggregations when near the coast are likely to be close to, but inshore of, the tidal fronts which occur parallel to and between the 50 and $70 \mathrm{~m}$ isobaths in the southeastern Bering Sea (Schumacher et al. 1979, Kinder et al. 1983, Coyle \& Cooney 1993). If enhanced levels of phytoplankton are present in the vicinity of these inshore fronts as they were around the Pribilof Islands (Coyle \& Cooney 1993), these frontal areas may be particularly attractive to foraging euphausiids. Thus, although the fronts are not necessary for the entrapment of vertically migrating euphausiids, the presence of a front and its associated concentrations of phytoplankton may lead to more elevated numbers of euphausids in shallow water than might have occurred in the absence of the fronts.

Coyle et al. (1992) described a third mechanism whereby euphausiids can be forced to remain in shallow water where they are vulnerable to avian predators. At a reef east of St. George Island, murres (Uria spp.) foraged on euphausiids that were prevented from descending to depth by tidal currents that impinged upon the reef and counteracted the downward swimming of the euphausiids. A similar combination of a tidal pump and shallow bathymetry may be responsible for the large aggregations of foraging shearwaters in the passes of the Aleutian Islands (Troy \& Bradstreet 1991, Schneider \& Shuntov 1993, Hunt unpubl. data). Elsewhere, Vermeer et al. (1987) and Brown \& Gaskin (1988) described situations in which extremely strong tidal currents interacting with bathymetry force euphausiids to the surface where they are fed upon by surface-foraging birds.
Acknowledgements. We thank the graduate students and volunteers from the University of California, Irvine. The University of California Research Expeditions Program, and the Unversity of Alaska, Fairbanks, and the Captain and crew of the 'Alpha Helix' for their assistance during the cruises. R. T' Cooney aided in field collections, planning and data interpretation. R. Russell aided with the statistical analysis. We thank W. Montevecchi and 2 anonymous reviewers for helpful comments on an earlier version of this paper. This research was supported by National Science Foundation, Division of Polar Programs grant DPP85-09843, and by the University of California Research Expeditions Program.

\section{LITERATURE CITED}

Brown RGB, Gaskin DE (1988) The pelagic ecology of the grey and red-necked phalaropes Phalaropus fulicarius and $P$. lobatus in the Bay of Fundy, eastern Canada. Ibis 130:234-250

Coyle KO, Cooney RT (1993) Water column sound scattering and hydrography around the Pribilof Islands, Bering Sea. Cont Shelf Res 13:803-827

Coyle KO, Hunt GL Jr, Decker MB, Weingartner TJ (1992) Murre foraging, epibenthic sound scattering and tidal advection over a shoal near St. George Island, Bering Sea. Mar Ecol Prog Ser 83:1-14

Franks PJS (1992) Sink or swim: accumulation of biomass at fronts. Mar Ecol Prog Ser 82:1-12

Gould PJ, Forsell DJ, Lensink CJ (1982) Pelagic distrıbution and abundance of seabirds in the Gulf of Alaska and the eastern Bering Sea. US Fish and Wildlife Service FWS/ OBS-82/48, Washington, DC

Green CH, Wiebe PH, Burczynski J (1989) Analyzing zooplankton size distribution using high-frequency sound. Limnol Oceanogr 34:163-178

Guzman J (1981) The wintering of sooty and short-tailed shearwaters (genus Puffinus) in the North Pacific. PhD thesis, University of Calgary

Hanamura X, Kotori M, Hamaoka S (1989) Daytime surface swarms of the euphausiid Thysanoessa inermis off the west coast of Hokkaido, northern Japan. Mar Biol 102: 369-376

Haney JC, Solow AR (1992) Testing for resource use and selection by marine birds. J Field Ornithol 63:43-52

Hunt GL Jr (1991) Occurrence of polar seabirds at sea in relation to prey concentrations and oceanographic factors. In: Sakshaug E, Hopkins CCE, Øritsland NA (eds) Proceedings of the Pro Mare Symposium on Polar Marme Ecology, Trondhelm, 12-16 May 1990. Polar Res 10(2):553-559

Hunt GL Jr, Burgeson B, Sanger GA (1981a) Feeding ecology of seabirds of the eastern Bering Sea. In: Hood DW, Calder JA (eds) The eastern Bering Sea: oceanography and resources. NOAA/BLM, Washington, DC, p 629-647

Hunt GL Jr, Croxall JP, Trathan PN (1994) Marine arnithology in the southern Drake Passage and Bransfield Strait during the BIOMASS programme. In: El-Sayed SZ (ed) Southern Ocean ecology: the BIOMASS perspective. Cambridge University Press, Cambridge, p 231-245

Hunt GL Jr, Eppley Z, Burgeson B, Squıbb R (1981b) Reproductive ecology, foods, and foraging areas of seabirds nesting on the Pribilof Islands, 1975-1979. Environmental assessment of the Alaskan continental shelf; final reports of principal investigators, Vol 12. NOAA/OMPA, Washington, DC, p 1-257

Hunt GL Jr, Gould PJ, Forsell DJ, Peterson H Jr (1981C) Pelaglc distribution of marine birds in the eastern Bering 
Sea. In: Hood DW, Calder JA (eds) The eastern Bering Sea shelf: oceanography and resources. NOAA/BLM, Washington, DC, p 689-718

Hunt GL Jr, Schneider DC (1987) Scale-dependent processes in the physical and biological environment of marine burds. In: Croxall JP (ed) Seabirds: feeding biology and role in marine ecosystems. Cambridge University Press, Cambridge, p 7-41

Kınder TH, Hunt GL Jr, Schneider D, Schumacher JD (1983) Correlation between seabirds and oceanic fronts around the Pribilof Islands, Alaska. Estuar Coast Shelf Scl 16: 309-319

Kinder TH, Schumacher JD (1981) Hydrographic structure over the continental shelf of the southeastern Bering Sea. In: Hood DW, Calder JA (eds) The eastern Bering Sea shelf: oceanography and resources. NOAA/BLM, Washington, DC, p 31-52

Kiørboe T (1993) Turbulence, phytoplankton cell size, and the structure of pelagic food webs. Adv Mar Biol 29:1-72

Kiørboe T, Munk P, Richardson K, Christiansen V, Paulsen H (1988) Plankton dynamics and herring larval growth, drift and survival in a frontal area. Mar Ecol Prog Ser 44: 205-219

Le Fèvre J (1986) Aspects of the biology of frontal systems. Adv Mar Biol 23:163-299

Morgan WH (1982) Feeding methods of the short-tailed shearwater Puffinus tenuirostris. Emu 82:226-227

Neu CW, Byers CR, Peek JM (1974) A technique for analysis of utilization-availability data. J Wildl Manage 38:541-545

Nielsen TG, Lokkegaard B, Richardson K, Pederson FB, Hansen L (1993) Structure of plankton communities in the Dogger Bank area (North Sea) during a stratified situation. Mar Ecol Prog Ser 95:115-131

Nishiyama T (1974) Energy requirement of Bristol Bay sockeye salmon in the central Bering Sea and Bristol Bay. In: Hood DW, Kelly EJ (eds) Oceanography of the Bering Sea with emphasis on renewable resources. Inst Marine Sci Occas Publ 2, University of Alaska, Fairbanks, p 321-343

Ogi $\mathrm{H}$ (1973) Preliminary examination of stomach contents of murres (Uria spp.) from the eastern Bering Sea and Bristol Bay, June-August, 1970 and 1971. Jpn J Ecol 23:201-209

Ogi $H$, Kubodera TK, Nakamura K (1980) The pelagic feeding ecology of the short-tailed shearwater Puffinus tenuirostris in the subarctic Pacific region. J Yamashina Inst Ornithol 12:157-182

Paul A.J, Coyle KO, Ziemann DA (1990) Timing of spawning of Thysanoessa raschii (Euphausiacea) and occurrence of their feeding stage larvae in an Alaskan bay. J Crust Bıol $10.69-78$

Pingree R, Pugh P, Holligan PM, Forster G (1975) Summer phytoplankton bloom and red tides in the approaches to the English Channel. Nature 258:672-677

Ponomareva LA (1963) Euphausids of the North Pacific Ocean; the distribution and ecology of the major species. Akademya Nauk, SSSR. Institut Okeanologin, Moskow /ln Russian|

Richardson K (1985) Plankton distribution and actuvity in the North Sea/Skagerrak-Kattegat frontal area in Aprll 1984. Mar Ecol Prog Ser 26:233-244

This article was presented by D. C. Schneider (Senior Editorial Advisor), St. John's, Newfoundland, Canada
Sambrotto RN, Niebauer HJ, Goering JJ, Iverson RL (1986) Relationships among vertical mixing, nutrate uptake, and phytoplankton growth during the spring bloom in the southeast Bering Sea middle shelf. Cont Shelf Res 5:161-198

Schnelder DC (1982) Fronts and seabird aggregations in the southeastern Bering Sea. Mar Ecol Prog Ser 10:101-103

Schneider DC, Harrison NM, Hunt GL Jr (1990) Seabird diet at a front near the Pribilof Islands, Alaska. Stud Avian Biol 14:61-66

Schneider DC. Hunt GL Jr, Harrison NM (1986) Mass and energy transfer to seabirds in the southeastern Bering Sea. Cont Shelf Res 5:241-257

Schneider DC. Shuntov VP (1993) The trophic organization of the marine bird community in the Bering Sea. Rev Fish Scl $1: 311-335$

Schumacher JD, Kinder TH, Pasinski DJ, Charnell RL (1979) A structural front over the continental shelf of the eastern Bering Sea. J Phys Oceanogr 9:79-87

Shuntov VP (1964) Transequitorial migrations of the thinbilled shearwater Puffinus tenuirostris (Temm.). Zool Zh 43:590-598 (in Russian)

Simpson JH, Edlestein DJ, Edwards A. Morris NCG, Tett PB (1979) The Islay Front: physical structure and phytoplankton distribution. Estuar Coast Mar Sci 9:713-726

Smith SE, Adams PB (1988) Daytime surface swarms of Thysanoessa spinifera (Euphausiaea) in the Gulf of the Farallones, California. Bull Mar Sci 42:76-84

Springer AM (1992) A review: walleye pollock in the North Pacific - how much difference do they really make? Fish Oceanogr 1:80-96

Tanaka Y, Kajihara $\mathrm{T}$ (1979) The distribution of Fulmaris glacialis and Puffinus tenuirostris in the North Pacific and the Okhotsk Sea during the summer J Yamashina Inst Ornithol 11:79-86

Tasker ML, Hope Jones P, Dixon T, Blake BF (1984) Counting seabirds from ships: a review of methods employed and a suggestion for a standardized approach. Auk 101:567-577

Troy DM, Bradstreet MSW (1991) Marine bird abundance and habitat use. In: Marine birds and mammals of the Unimak Pass Area: abundance, habitat use and vulnerability. LGL Alaska Research Associates, Inc. Final Report to Mineral Management Services, Anchorage, Contract MMS14-35001-30564, p 5-1 to 5-70

Troy DM, Johnson SR (1989) Marine birds, Section 6. In: Truett JC (ed) Environmental characterization and biological utilization of the North Aleutian Shelf nearshore zone. Outer Continental Shelf Environmental Assessment Program, Final Reports of Principal Investigators 60. NOAA, Washington, DC, p 355-453

van Franeker JA (1994) A comparison of methods for counting seabirds at sea in the Southern Ocean. J Field Ornithol 65: $96-108$

Vermeer K. Szabo I, Greisman P (1987) The relatıonship between plankton-feeding Bonaparte's and mew gulls and tidal upwelling at Active Pass, British Columbia. J Plankton Res 9:483-501

Whitledge TE, Reeburgh WS, Walsh JJ (1986) Seasonal inorganic nitrogen distributions and dynamics in the southeastern Bering Sea. Cont Shelf Res 5:109-132

Manuscript first received: May 26, 1995 Revised version accepted: July 10, 1996 